\title{
LITERATURE REVIEW \\ The medicinal value of honey: a review on its benefits to human health, with a special focus on its effects on glycemic regulation
}

\author{
Manuel E. Cortés ${ }^{1,2}$, Pilar Vigil ${ }^{2}$, and Gloria Montenegro ${ }^{3}$ \\ 'Departamento de Ciencias Animales, Facultad de Agronomía e Ingeniería Forestal, Pontificia Universidad \\ Católica de Chile. Casilla 306-22, Santiago, Chile. \\ ${ }^{2}$ Unidad de Reproducción y Desarrollo, Departamento de Fisiología. Facultad de Ciencias Biológicas, \\ Pontificia Universidad Católica de Chile. Casilla 114D, Santiago, Chile. \\ ${ }^{3}$ Departamento de Ciencias Vegetales, Facultad de Agronomía e Ingeniería Forestal, Pontificia Universidad \\ Católica de Chile. Casilla 306-22, Santiago, Chile.
}

\begin{abstract}
M.E. Cortés, P. Vigil, and G. Montenegro. 2011. The medicinal value of honey: a review on its benefits to human health, with a special focus on its effects on glycemic regulation. Cien. Inv. Agr. 38(2): 303-317. Honey, a natural substance produced by honeybees, is composed of a complex mixture of carbohydrates, water, and a small amount of proteins, vitamins, minerals, and phenolic compounds. Fructose, glucose and maltose are among the various types of sugars present in honey. Used for millennia as both food and medicine, honey has been associated with improved antioxidant capacity, modulation of the immune system, antimicrobial activities, influence on lipid values (through antihypercholesterolemic effects) and regulation of glycemic responses, among other benefits. The aim of this article was to review the effects of natural honey intake on human health, with particular reference to its influence on glycemic regulation. Several studies have focused on the potential use of honey as a nutritional supplement for healthy individuals and for those with impaired glucose tolerance, diabetes, and their related comorbidities. Such investigations have found that, compared to glucose and sucrose, the consumption of honey decreases glycemic levels and blood lipids in healthy, diabetic and hyperlipidemic individuals. Moreover, long periods of honey intake seem to reduce fasting glucose levels in humans, suggesting that honey consumption influences plasma glucose regulation, mainly through a normo- or hypoglycemic effect. Therefore, honey may be proposed as a nutritional dietary supplement for healthy individuals and for those suffering from alterations in glycemic regulation.
\end{abstract}

Key words: Diabetes, flavonoids, glycemic regulation, honey, insulin resistance, nutraceuticals, nutrition.

\section{Introduction}

Honey is a natural substance of sweet flavor and viscous consistency produced by honeybees, especially by the species Apis mellifera.

Received March 12, 2010. Accepted March 23, 2011.

Corresponding author: manuelcortes@uc.cl
Honey was probably the first sweetener discovered by man, and its use dates back to the origins of mankind itself (Havsteen, 2002); in fact, honey reportedly constituted a component of the Paleolithic diet (Eaton and Eaton, 2000). There is evidence of the development of beekeeping in the Neolithic, as shown in cave paintings found in Cueva de la Araña, near Bicorp, Valencia, Spain, which depict honey 
being collected by a prehistoric man using a makeshift beehive. Records of its use have been found in Sumerian clay tablets dated 2100-2000 years B.C. (Yaghoobi et al., 2008). In Egypt, beekeeping underwent remarkable development, and representative products of the apiary (e.g., beeswax, honey, pollen, propolis, and royal jelly) were used both as medicine and ceremonial materials, and jars containing residues of honey and related substances have been found in the tombs of several pharaohs (Havsteen, 2002), such as that of Tutankhamun (Kahn et al., 2007). In Greece and Rome, honey was also utilized as medicine and energy food (García et al., 1986; Garret and Grisham, 2001); in India, it has been of great relevance in Ayurvedic Medicine and Unani Medicine for centuries (Aparna and Rajalakshmj, 1999; Agrawal et al., 2007). The therapeutic effect of honey was also known in Persia, as mentioned by the scientist, philosopher and physician Avicenna approximately 1000 years ago in his remarkable book, Canon of Medicine (Avicenna, 1999). In Medieval Europe, beekeeping continued to develop, and later, during the Renaissance, it also inspired artists, such as the Florentine painter Piero di Cosimo, author of "The Discovery of Honey" (Thomas and Mathews, 1963; Garret and Grisham, 2001). Later, in the XVII century, the Tratado Breve sobre la Cultivación de las Colmenas was transcribed in Spain (de Jesús María, 1653) and is one of the earliest works on beekeeping to be written in Spanish. Thus, honey has occupied an important role in the human diet from the dawn of mankind to the present day.

Currently, honey is widely used for nourishment, constituting a nutritious supplement with medicinal properties recognized all over the world (Montenegro et al., 2003); this has led to its current use in the treatment of a number of pathologies (Molan, 2001; Kahn et al., 2007) and justifies its nomination as a functional aliment or 'nutraceutical.' Honey is produced in almost every country of the world and is recognized as an important energy food (Muñoz et al., 2007). Because of its high nutritious value and unique flavor, honey has become increasingly accepted by consumers, often being used as a substitute for other sweeteners (Montenegro et al., 2003).
Nevertheless, it is not to be considered a whole food according to human standards but rather as a potential dietary supplement (Muñoz et al., 2007). The world production of honey today comprises approximately 1.2 million tons, less than $1 \%$ the total production of sugar (ÁlvarezSuárez et al., 2010). The demand for honey varies remarkably from one country to another, and China and Argentina rank among the main exporters; these countries, however, have low annual consumption rates, close to 0.1 to 0.2 kg per capita (Álvarez-Suárez et al., 2010). Indeed, honey consumption is higher in developed countries, where domestic production does not meet the market demand (Álvarez-Suárez et al., 2010). In Chile, honey is produced by approximately 14,000 beekeepers, and there are over 335,000 apiaries, which produce different varieties of unifloral and polyfloral honey (Muñoz et al., 2007).

Considering the wide interest generated since ancient times by the medicinal and nutritional properties associated with honey, the objective of this review article was to summarize the main benefits attributed to the intake of natural honey, with a special focus on the effects exerted on glycemic regulation.

\section{The composition of honey}

Honey is composed of a complex mixture of water, carbohydrates and a myriad of other minor compounds (White, 1978; García et al., 1986). The chemical composition of honey is variable and depends on regional and climatic conditions and on the type of flowers visited by the bees, thus, its classification as unifloral or polyfloral (Fredes, 2004; Muñoz et al., 2007; Fredes and Montenegro, 2008). However, on average, natural honey is composed of $17.1 \%$ water, $82.4 \%$ carbohydrates - approximately $38.5 \%$ fructose, $31 \%$ glucose and $12.9 \%$ other sugars- and $0.5 \%$ proteins, amino acids, vitamins, phenolic compounds, organic acids and multiple minerals, among other minority constituents (White, 1978; García et al., 1986; Garret and Grisham, 2001; Moreira and De Maria, 2001; Fredes, 2004; Fredes and Montenegro, 2006; Kahn et al., 2007; Montenegro and Fredes, 2008). It has 
also been suggested that the presence of variable amounts of heavy metals can be related to the geographical and botanical origin of this product (Fredes, 2004; Fredes and Montenegro, 2006).

In natural honey, as well as in propolis and royal jelly, most of the phenolic compounds are present in the form of flavonoids (Viuda-Martos et al., 2008), a vast family of phytochemicals comprising chalcones, flavandiols, flavonols, anthocyanins and proanthocyanidins. Flavonoid biosynthesis is derived from the phenylpropanoid pathway, one of the most widely studied secondary metabolic routes in plant systems. Several phenolic compounds, especially flavonoids, are associated with multiple benefits on human health, including anti-inflammatory, antioxidant, antiallergic, antithrombotic, antidiabetogenic, hypoglycemic, normolipidemic, hepatoprotective, antiviral and anticarcinogenic activities (Havsteen, 2002; Middleton et al., 2000; Pérez-Trueba, 2003). Due to these properties, flavonoids have been recognized as nutraceutical compounds (Tapas et al., 2008). Regarding the flavonoids identified in Chilean honeys, it is important to highlight specific compounds, such as chrysin, galangin, isorhamnetin, kaempferol, myricetin, naringenin, pinobanksin, pinocembrin, quercetin, and rutin (Muñoz et al., 2007; Montenegro et al., 2009). The specific effects of these compounds on glucidic metabolism will be described further below.

\section{Honey has been linked to several beneficial effects on human health}

As mentioned above, for millennia honey has been credited with multiple medicinal properties (Figure 1). In the following section, some of these properties are explained in more detail.

\section{Enhanced antioxidant activity}

It is known that free radicals and reactive oxygen species (ROS), such as hydroperoxyl, hydroxyl, and superoxide, are associated with aging and disease mechanisms. ROS can produce oxidative damage in biomolecules, such as carbohydrates, lipids, proteins and nucleic acids, which can alter various cell processes and cause cell death (Viuda-Martos et al., 2008). Several studies have found that the consumption of honey can improve the defenses against oxidative stress (Al-Mamary et al., 2002; Schramm et al., 2003; Beretta et al., 2007; van der Berg et al., 2008). This function has been attributed to the natural phenolic compounds (e.g., flavonoids) in honey (Pérez-Trueba, 2003; Schramm et al., 2003; van der Berg et al., 2008). These phytochemicals appear to exert their antioxidant capacities mainly through the decrease and removal of ROS, thus diminishing the risk of pathologies and damage produced by free radicals (Beretta et al., 2007). The exact molecular

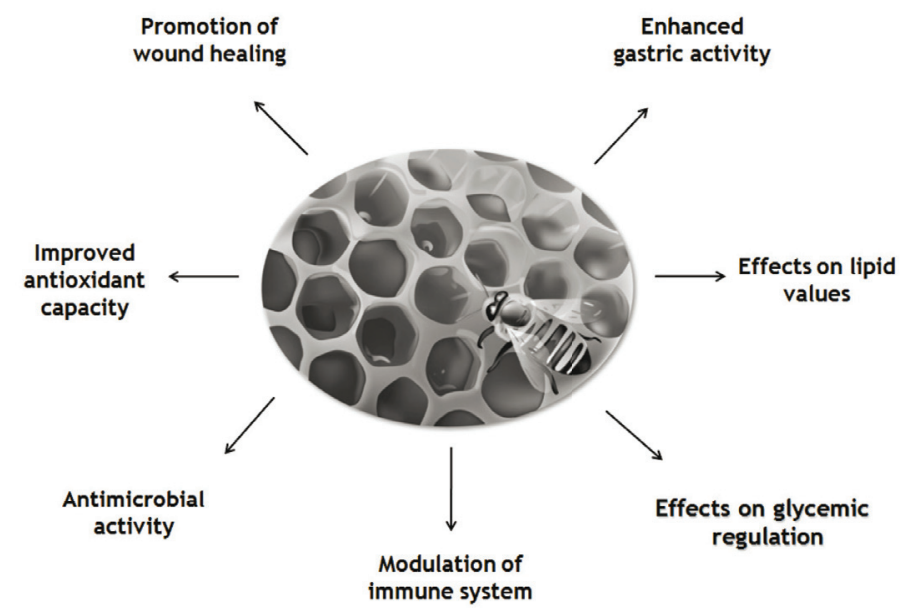

Figure 1. Main effects on human health attributed to natural honey intake. 
mechanisms of antioxidant activity of the phenolic compounds present in honey and related beehive products are not yet fully understood. However, the most probable ones include free radical scavenging, hydrogen donation, the interference with propagation reactions or inhibition of enzymatic systems involved in initiation reactions, metallic ion chelation, and acting as a substrate for diverse free radicals, especially ROS (van Acker et al., 1996; Al-Mamary et al., 2002; Havsteen, 2002; Middleton et al., 2000; Viuda-Martos et al., 2008).

\section{Effects on the immune system}

It has been suggested that the consumption of honey can exert several beneficial effects on the human immune response and on its associated mechanisms. In fact, honey has been reported to promote the multiplication of human peripheral blood B- and T-lymphocytes and the activation of neutrophils under conditions of cell culture (Abuharfeil et al., 1999). In monocytic cell line culture, honey has been shown to stimulate the release of inflammatory cytokines, such as tumor necrosis factor-alpha, interleukin-1 $\beta$ and interleukin-6 (Tonks et al., 2003), which are involved in triggering a number of functions of the immune response to infection (Molan, 2001). Moreover, in mice, it has been found that the intake of a honey-supplemented diet stimulates the production of antibodies during the primary and secondary immune responses against thymus-dependent and -independent antigens (Al-Waili and Haq, 2004). A recent study reported an immuno-modulatory potential of honey in the course of phagocytosis, mainly by modifying the oxidative burst process through the inhibition of phagocytic myeloperoxidase activity and an inhibitory effect exerted by the major sugar constituents of honey on exocytosis-associated ROS formation catalyzed by myeloperoxidase (Mesaik et al., 2008).

\section{Antimicrobial activity}

Honey and beehive-related substances have been used as antiseptic agents (e.g., propolis) since at least the time of Aristotle (Molan,
2001). Despite the evident antimicrobial capacity of honey, as determined by its effective inhibition of bacterial and fungal proliferation and growth, there does not seem to be any clear-cut cause, suggesting that it could correspond to a combined or synergic effect of the antioxidant compounds present (Viuda-Martos et al., 2008). The following properties have been proposed to explain the effect of honey against bacterial growth: (i) the presence of hydrogen peroxide, resulting from the action of the glucose-oxidase enzyme on glucose in presence of oxygen (García et al., 1986; Wahdan, 1998; Molan, 1999a, Khan et al., 2007), a compound whose activity appears to decrease as honey remains in storage (Montenegro et al., 2009); (ii) inherent physicochemical properties, such as its high sugar content $(\sim 80 \% \mathrm{w} / \mathrm{w})$ that can produce a high osmotic effect and its acid pH of 3 to 4.5 (Molan, 1992; Bogdanov et al., 1997); (iii) the presence of diverse organic acids (Aparna and Rajalakshmj, 1999), including gluconic acid (also derived from glucose catalysis), which remarkably creates an acidic microenvironment and whose concentration varies considerably from one type of honey to another (White et al., 1963; White, 1978); and (iv) non-peroxidic substances (Cabrera et al., 2006), such as polyphenols, which possess antibacterial activity. These compounds vary depending on the plant species from which the bees gather their nectar (Cooper, 2007) and seem to remain unaltered even after long periods of storage (Viuda-Martos et al., 2008). With regard to the antibacterial activity, it has been recently determined that extracts of unifloral honeys from the endemic Chilean tree, Quillay (Quillaja saponaria), which contain several natural phenolic compounds, show antibacterial activity against Escherichia coli, Pseudomonas aeruginosa, Staphylococcus aureus, Salmonella typhi, Streptococcus pneumoniae type $\beta$, and Vibrio cholerae, and antifungal activity against Candida albicans (Montenegro et al., 2009).

Lastly, due to its antimicrobial properties, the use of natural honey has also been recommended in medical treatments for promoting wound disinfection and healing (Khan et al., 2007). Thus, some physicians have also advised their patients to use honey to improve the healing of surgical scars (Molan, 1999b; Molan, 2001; Khan et al., 2007). 


\section{Effects on glycemic regulation}

The term 'glycemic regulation', also known as 'glycemic homeostasis', refers to diverse phenomena leading to the adequate regulation of blood glucose levels (i.e., glycemia), which constitutes one of the mechanisms used by organisms to maintain the properties of their internal milieu constant. For decades, there has been interest in determining the effects of honey intake on glucose regulation disorders, and controversial results have been obtained. On the one hand, it has been considered that honey consumption by diabetics is pointless because it contains a considerable proportion of sugars (White, 1978; Moreira and De Maria, 2001), while on the other hand, some research has produced interesting results positioning honey as a potential nutritional supplement for subjects with disorders of glucose homeostasis (Bornet et al., 1985; Samanta et al., 1985; Katsilambros et al., 1988; Shambaugh et al., 1990; Al-Waili, 2004; Agrawal et al., 2007; Ahmad et al., 2008).

Before referring to the effects of honey intake on the alterations in glycemic regulation, it is necessary to examine such disorders in detail, as described below.

\section{a. Disorders of glucose regulation and their} associated comorbidities. There can be as many alterations in glucose metabolism as the existing mutations in some of the enzyme-encoding genes associated with their metabolic pathways, e.g., deficiency of phosphofructokinase-1, hepatic fructose 1,6-biphosphate aldolase or ketohexokinase. These pathologies are commonly termed inborn errors of glucidic metabolism (Hall, 2003). However, the most relevant disorders that are recognized today as related to glucidic homeostasis are those linked to alterations in the regulation of glycemia by insulin. Insulin is a peptide hormone produced in the pancreas, specifically by pancreatic-beta cells; it is composed of 51 amino acids, and the gene that encodes it is located in chromosome 11 in humans (Vincent-Desplanques et al., 2005). Insulin has multiple functions in an organism, such as protein and hepatic glycogen synthesis, triacylglycerol storage in adipose tissue, and, probably the most important func- tion, the regulation of glycemic levels, which promote glucose uptake by its target cells, especially in muscle, the liver and adipose tissue. To exert this function, insulin must bind to its plasma membrane receptor and trigger a cascade of intracellular signaling, which eventually leads to the translocation of glucose transporters, mainly GLUT4, to the plasma membrane, resulting in glucose uptake.

When a certain amount of insulin is secreted by the pancreas, the corresponding effector organ responds depending on its insulin sensitivity (Ferrannini and Mari, 1998). Defects in this mechanism lead to a pathophysiological state known as insulin resistance, which has been defined as a condition in which a normal insulin concentration produces an attenuated biological effect in terms of glucidic homeostasis (Yalow and Berson, 1970), decreasing the ability of this hormone to exert its functions on its aforementioned typical target tissues. When insulin cannot exert its normoglycemic actions, blood glucose can increase to dangerous concentration levels and, additionally, be accompanied by compensatory hyperinsulinemia (i.e., excessive circulating insulin) to diminish the increased glucose levels (Cordain et al., 2003). The latter constitutes one of the initial stages of diabetes mellitus. Several types of insulin resistance have been reported (Vincent-Desplanques et al., 2005), a condition also linked to the development of diverse pathologies, such as obesity, as insulin is a fundamental regulator of virtually every aspect of adipocyte biology (Khan and Flier, 2000). This hormone promotes the storage of triacylglycerols in adipocytes via a number of mechanisms, which include the differentiation from preadipocytes to adipocytes. Moreover, in mature adipocytes, insulin stimulates the transport of glucose and the synthesis of triacylglycerols - a phenomenon known as lipogenesis - and inhibits lipolysis (Khan and Flier, 2000). In addition, insulin increases the uptake of fatty acids derived from circulanting lipoproteins by stimulating the activity of the lipoprotein lipase, in adipose tissues (Khan and Flier, 2000).

Currently, the pathology known as insulin resistance has acquired remarkable importance 
because it has been proposed to be a crucial component of what is known as 'metabolic syndrome', which consists of the combination of several pathologies or risk factors in a single individual, increasing the susceptibility to cardiovascular disease and diabetes. Yet, a portion of the scientific community is still debating on whether to consider insulin resistance a component and/or diagnostic criterion of metabolic syndrome (Reaven, 2006). In any case, metabolic diseases have a high prevalence in society today. This is especially true for diabetes, the main endocrine illness worldwide, with 150 million reported diabetics, and estimates indicate this number could double by 2025 (King et al., 1998). Factors, such as genetic predisposition, a sedentary lifestyle and stress, are implicit in the genesis of diabetes, together with a high-calorie diet based mainly upon the intake of excessively fatty or sweet food; indeed, it is known that the consumption of food with a high-sugar content often constitutes one the central causes of the origin of several endocrine-metabolic disorders (Cordain et al., 2003). In this respect, the prominent French physiologist and physician, Claude Bernard, suggested in the XIX century that the sensitivity to carbohydrates could be modulated by dietary intake (Shambaugh et al., 1990). Thus, increasing the level of sucrose would lead to a deterioration of glucose tolerance and trigger harmful health effects (Shambaugh et al., 1990).

There is also an existing link between alterations in glucose and insulin levels and several reproductive problems in humans (Zitzmann, 2009). Insulin resistance is considered an important factor linked to ovulatory dysfunction in women (del Río et al., 2006; Vigil et al., 2007a) and to hypogonadism and associated disorders in men (Contreras et al., 2006; del Río et al., 2007; Zitzmann, 2009). Additionally, impaired glucose tolerance and obesity, among other factors related to insulin resistance in women, also have a negative impact on fertility (del Río et al., 2006; Vigil et al., 2007a; Vigil et al., 2007b). As to the latter, several studies have reported that such endocrine-metabolic pathologies and their comorbidities are associated with polycystic ovary syndrome, a disorder defined as an ovulatory dysfunction caused by hyperandrogenism, which is highly prevalent worldwide among reproductive-aged women (del Río et al., 2006; Vigil et al., 2007a; Vigil et al., 2007b).

\section{b. Effects of honey intake on glycemic regula-} tion. A number of studies have focused on this topic, and among them, Samantha et al. (1985) have shown that the intake of honey has a lower hyperglycemic response, as compared to glucose and sucrose, in healthy or type 1 diabetic individuals. Later, Bornet et al. (1985) have studied subjects suffering from diabetes mellitus type 2, and found that honey, compared to an isoglucidic amount of bread, presented no additional hyperglycemic effect in the diabetic individuals when consumed for breakfast (Bornet et al., 1985). In relation to this, yet another study has reported that, rather than producing a higher postprandial hyperglycemic effect, honey causes a hyperglycemia similar to that produced by consuming bread in individuals with type 2 diabetes (Katsilambros et al., 1988). Shambaugh et al. (1990) have studied non-diabetic subjects and reported that honey has a lower effect on increasing the levels of sugar in the blood, compared to sucrose; in addition, these authors have suggested that honey would cause fewer longterm health problems than fructose or sucrose, in part because it contains nutrients other than carbohydrates (Shambaugh et al., 1990; Shambaugh et al., 1991). Moreover, honey is sweeter that sucrose, thus, a smaller amount is required. Considering these advantages, the above authors have suggested that it should be favored as sweetener instead of sucrose (Shambaugh et al., 1990). Another study found that honey intake, when compared to glucose and sucrose, resulted in reduced glucose levels, blood lipids and $\mathrm{C}$ reactive protein (CRP) - a marker of inflammation and oxidative damage - in healthy, diabetic and hyperlipidemic subjects (Al-Waili, 2004). Agrawal et al. (2007) have reported that individuals with reduced glucose tolerance or mild diabetes, who were subjected to an oral glucose tolerance test one day and an oral honey tolerance test the next day, showed a higher tolerance to honey, indicating that honey could be a valuable substitute for sugar for people suffering from these metabolic pathologies (Agrawal 
et al., 2007). More recent studies support the findings of the latter and have reported that physiological glycemic responses were significantly lower in subjects who consumed natural honey, compared to those who consumed glucose or artificial honey (Ahmad et al., 2008). Moreover, another recent study has shown that a regimen of a 30-day honey intake seems to slightly reduce fasting blood glucose levels in humans (Yaghoobi et al., 2008).

c. How could honey be exerting regulatory effects on glycemic responses? The modulation of glycemic responses (normoglycemic and hypoglycemic effects) observed after natural honey intake could be based on diverse mechanisms of action that have not yet been completely elucidated. Honey contains many trace elements, such as antioxidants, copper, zinc, and unidentified components (White, 1978; Fredes, 2004; Fredes and Montenegro, 2006; Montenegro and Fredes, 2008); in addition, its fructose and glucose content can play an important role in such effects (Yaghoobi et al., 2008). The various putative underlying explanations are the following. 1) A slow decrease in saccharide absorption in the intestine is caused by the presence of glycemic carbohydrates in natural honey (Southgate 1995; Vosloo, 2005; Ahmad et al., 2008); in addition, fermentable and non-fermentable carbohydrates from natural honey could be linked to the modulation of intermediary metabolism in the intestinal lumen (Wang and Gibson, 1993; Kok et al., 1998; Shamala et al., 2000; Chow, 2002; Ahmad et al., 2008). It has been argued that the glucose component in honey is poorly absorbed by the gut epithelium (Agrawal et al., 2007). Furthermore, the presence of certain sugars, such as palatinose (isomaltulose), would interfere with glucose absorption (Oizumi et al., 2007). Thus, possible differences in carbohydrate absorption could also result in differences in glycemic control (Chepulis, 2007). 2) The effect is due to the hydrogen peroxide present in honey, which has been reported as an agent that can effectively mimic the function of insulin (Hayes and Lockwood, 1987), even though there is no evidence yet to prove that hydrogen peroxide is absorbed in the gut or that the levels produced are sufficient to activate insulin receptors (Chepulis, 2007). 3) Some compounds, which may also possess insulin-like activity, from the hypopharyngeal glands of honeybees are added to honey (Münstedt et al., 2009a). 4) The influence of honey on glycemic control is through its effects in decreasing prostaglandin and increasing nitric oxide (NO) levels (Yaghoobi et al., 2008). This mechanism may participate in glycemic modulation, as it has been shown that prostaglandin E2 is one of the main physiological inhibitors of insulin (Cheng et al., 2003), and higher levels of NO stimulate the increase of insulin secretion (Smukler et al., 2002). 5) There is an antioxidant activity exerted by some nonsugar components of honey, specifically, natural phenolic compounds, such as flavonoids. Regarding the antioxidant effects of flavonoids, it has recently been reported (Sharma et al., 2008) that rats with streptozotocin-induced diabetes showed a decrease in their postprandial glycemic responses after the administration of extracts of E. jambolana seeds, which have been attributed with antidiabetogenic, hypoglycemic and hypolipidemic effects (Sharma et al., 2008). Interestingly, extracts from this medicinal Hindu plant possess the compounds, rutin, myricetin, quercetin and kaempferol (Sharma et al., 2008), and, as mentioned above, these are some of the compounds identified in natural honey (Muñoz et al., 2007; Viuda-Martos et al., 2008; Montenegro et al., 2009). Various studies using mainly mice and rats as experimental models have shown that such flavonoids exert diverse normoglycemic effects and lead to a lower incidence of complications associated with diabetes (Lee et al., 2005; Fang et al., 2008; Zanatta et al., 2008; Fernandes et al., 2009; Kobori et al., 2009). In particular, it has been shown that chrysin and chrysin-derived compounds have hypoglycemic effects in diabetic mice (Shin et al., 1999). The polyhydroxylated flavonol, myricetin, has also been associated with the stimulation of lipogenesis and glucose transport in rat adipocytes (Ong and Khoo, 1996); it has been speculated that such a compound may exert an influence on the treatment of non-insulindependent diabetes mellitus (Ong and Khoo, 1996; Ong and Khoo, 2000). Kaempferol could act on multiple molecular targets to ameliorate hyperglycemia, including acting as a partial agonist of peroxisome proliferator-activated receptor gamma (Fang et al., 2008), whereas its 
derivative, kaempferol 3-neohesperidoside, has shown to possess an insulinomimetic effect in rat muscle (Zanatta et al., 2008). In addition, quercetin has also been linked to an improvement in glucose uptake (Fang et al., 2008) and diabetes-related symptoms in rats (Kobori et al., 2009), with similar results having been found in rutin-administered rats (Fernandes et al., 2009). In addition, isorhamnetin-3-O-beta-D-glucoside, a compound derived from flavonol isorhamnetin, also reportedly found in Chilean natural honeys (Montenegro et al., 2009), has proven to be effective in the prevention or treatment of diabetes-associated complications in various rat tissues (Lee et al., 2005). Apigenin, another flavonoid found in honey and related substances (Viuda-Martos et al., 2008), has shown to decrease hyperglycemia, disease-provoked thyroid dysfunction and lipid peroxidation in alloxan-treated diabetic mice (Panda and Kar, 2007). Lastly, naringenin has been shown to prevent dyslipidemia and hyperinsulinemia in low-density lipoprotein (LDL) receptor-null mice with diet-induced insulin resistance (Mulvihill et al., 2009). The aforementioned evidence leads to the idea that such flavonoids, which are present in natural honey, could be exerting their antidia- betogenic, normoglycemic and normolipidemic properties at a molecular signaling level (Middleton et al., 2000; Havsteen, 2002; Sharma et al., 2008), mainly by decreasing the alterations caused by oxidative stress. The latter can be understood in light of the increasing acceptance by the scientific community that an imbalance in the oxidative state, such as that induced by abnormal ROS levels, is a phenomenon linked to cellular insulin resistance, dysglycemias and related pathologies (Evans et al., 2005; Eriksson, 2007; Martínez-Hervas et al., 2008; Choi et al., 2008). ROS accumulation can lead to the inadequate activation of stress kinases, damage in cellular membranes, dysfunction in organelles, such as the endoplasmic reticulum and mitochondria, and in the genome (Muoio and Newgard, 2004; Eriksson, 2007; Choi et al., 2008). In addition, inadequate oxidative modification of cell carbohydrates, lipids and proteins can have functional consequences contributing to the development and progression of insulin resistance (Evans et al., 2005). Regarding the above, the flavonoids or other phenolic compounds present in the various types of natural honeys could be exerting their effects on glycemic control at an intracellular level by decreas-

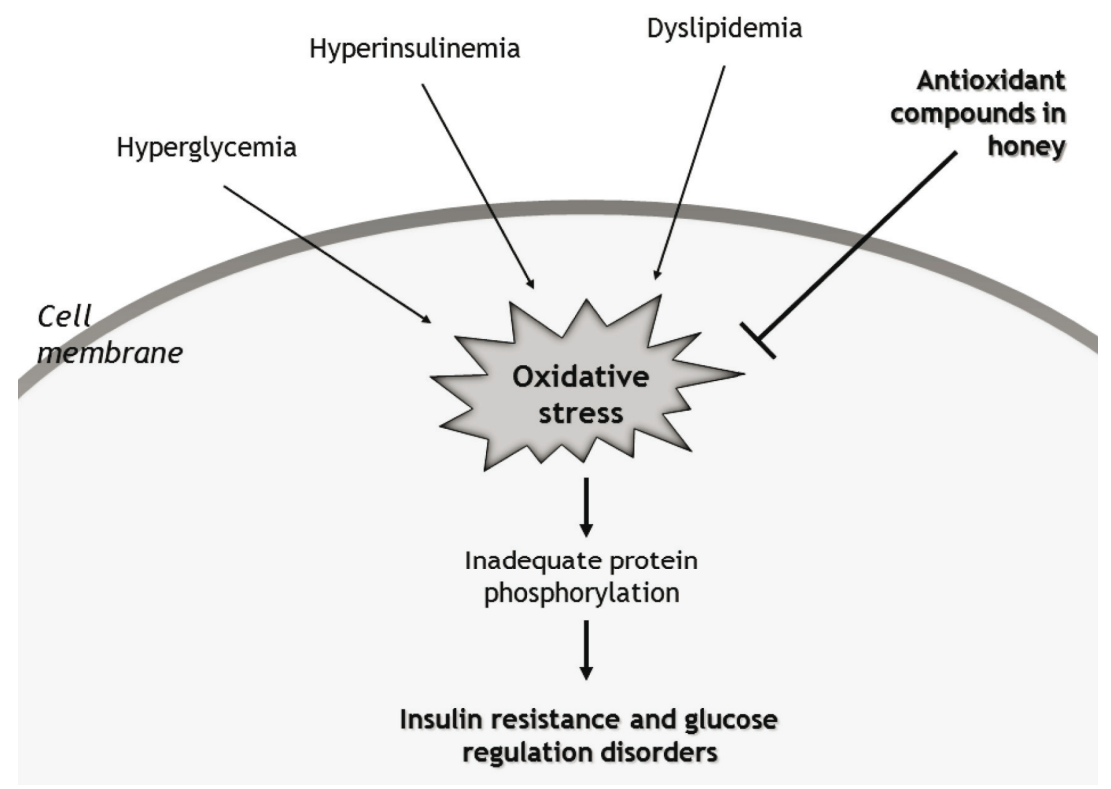

Figure 2. One of the proposed hypothetical mechanisms through which several antioxidants (mainly flavonoids and other phenolic compounds), which are present in natural honey, may act against the development of glycemic regulation disorders by decreasing the oxidative stress caused by metabolic alterations, such as hyperglycemia, hyperinsulinemia and dyslipidemia. 
ing the oxidative alterations linked to insulin resistance, hyperglycemia and other associated pathophysiological states (Figure 2). 6) It is possible that flavonoids could directly stimulate an otherwise weak insulin effect in various ways, for example, by directly influencing phosphokinase proteins (Havsteen, 2002). 7) Lastly, in a similar way as mentioned above for carbohydrates, the flavonoids present in honey could also be directly blocking carbohydrate transport at the intestine level. This is remarkably interesting regarding the treatment of diabetes from a pharmacological point of view. By measuring saccharide transport in Xenopus laevis oocytes (Kwon et al., 2007), myricetin, fisetin, and quercetin, and their glycoside precursor, isoquercitrin, compounds which are all present in beehive products (Viuda-Martos et al., 2008), have been reported to initiate a strong inhibition of the fructose and glucose transport mediated by GLUT2 (Kwon et al., 2007).

Nevertheless, the aforementioned explanations do not exclude the possible mediation of the beneficial effects of honey intake on glucose homeostasis disorders by other mechanisms not yet described.

\section{Effects on lipid homeostasis}

A few studies have focused on the influence of oral honey consumption on the regulation of human lipid values (Al-Waili, 2004; Yaghoobi et al., 2008; Münstedt et al., 2009b). It has been reported that, even though a single dose of glucose or artificial honey (consisting of $40 \mathrm{~g}$ fructose +35 g glucose in $250 \mathrm{~mL}$ water) leads to an increase in cholesterol and triacylglycerols 1 to $3 \mathrm{~h}$ later, this effect is not observed with natural honey (Al-Waili, 2004). Furthermore, a 15-day daily intake of $75 \mathrm{~g}$ of honey by hyperglycemic and hyperlipidemic individuals has resulted in a decrease of plasma glucose, lipid levels and CRP (Al-Waili, 2004). Another study using honeydew honey with a high antioxidant content has indicated that HDL cholesterol increased significantly in rats fed the honey, compared to that of the group fed on a sugar-free diet (Chepulis, 2007; Chepulis and Starkey, 2008). However, it has been reported that a 30 -day natural honey intake in overweight or obese human subjects caused a non-significant decrease in cholesterol (Yaghoobi et al., 2008). Lastly, a recent study of male and female subjects who randomly received a 75-g honey solution or a sugar solution similar to honey for 14 days has shown that the male LDL-cholesterol values were not significanly reduced by the honey supplementation; however, in women, these values increased in the group that received the sugar solution but not in that fed honey (Münstedt et al., 2009b). Therefore, female LDL-cholesterol values may be slightly reduced by substituting sugar with honey in the daily diet, evidencing an antihypercholesterolemic effect as a result of honey consumption (Münstedt et al., 2009b).

The mechanisms through which honey exerts this modulation on lipid values are not yet fully understood. However, it is worth considering that the mechanisms inherent to lipid homeostasis are intimately linked to those of glycemic homeostasis; in fact, both are occasionally referred to as 'energy homeostasis'. Thus, the explanations regarding the effects exerted by honey consumption on lipid values are closely related to those mentioned above for the action of honey intake on glycemic regulation. Considering the high current worldwide prevalence of lipid profile alterations, highly associated with the development of cardiovascular pathologies and metabolic disturbances, the aforementioned evidence would suggest that honey could be used as a nutritional supplement to enhance the lipid values of those individuals suffering from these pathologies.

\section{Concluding remarks}

The aim of this review was to summarize the main benefits attributed to the intake of natural honey, with special emphasis on the effects exerted on glycemic regulation. The endocrinemetabolic pathologies mentioned here (e.g., impaired glucose tolerance, insulin resistance, diabetes, and obesity) have been shown to be currently increasing in prevalence and incidence all over the world (Braguinsky, 2002; Cordain et al., 2003). This increase may reflect, in part, a rather sedentary lifestyle and the effects gen- 
erated by changes in the nutritional pattern experienced by world's population in the past few decades. It is known that diet exerts a significant role in plasma glucose modulation and insulin levels (Marsh and Brand-Miller, 2005); however, regardless of the significance of this fact, there has been a lack of knowledge with regard to dietary management for subjects suffering from such disorders, and studies have been focused on promoting energy-restricted diets rather than on modifying the diet composition per se (Marsh and Brand-Miller, 2005). It has been argued that individuals suffering from problems affecting glycemic regulation cannot base their diet on the same nutritional pattern as the healthy population because such patterns include foodstuffs that promote or aggravate those pathologies. Avoiding the intake of sugars and sweets has been found to be particularly advisable to maintain an adequate plasma glucose level. However, this seems somewhat pointless, considering that carbohydrates constitute an important component of the diet, as glucose is the main source of energy for the central nervous system (Agrawal et al., 2007). Regarding the latter, it should be of great interest for agricultural, food, nutritional and health sciences to be able to implement nutritional alternatives to provide these individuals with functional food supplements with medicinal properties, especially as related to glycemic regulation. Natural honey, with therapeutic qualities widely recog- nized worldwide, should be among these supplements.

Despite the interesting evidence presented here, the topic merits further research, particularly with regard to understanding the specific mechanisms of action through which natural honey intake may be modulating glycemic responses. Further studies should determine and investigate those underlying mechanisms based on the impact their understanding may have in medical and nutritional approaches for individuals with glucose regulation disorders. Our research group is currently working towards the elucidation of this topic.

\section{Acknowledgements}

M. E. Cortés thanks Comisión Nacional de Investigación Científica y Tecnológica (CONICYT, Chile) and Facultad de Agronomía e Ingeniería Forestal, Pontificia Universidad Católica de Chile, for the scholarships granted for Ph.D. studies in Agricultural Sciences. The authors also wish to thank the Fondo Nacional de Desarrollo Científico y Tecnológico (FONDECYT-REGULAR 2011), for funding within the scope of the project: "Bioindicators of botanical and geographical origin of Chilean endemic honeys", Project 1110808 to G. Montenegro.

\section{Resumen}

M.E. Cortés, P. Vigil y G. Montenegro. 2011. Valor medicinal de la miel: beneficios en la salud humana, con especial referencia en sus efectos sobre la regulación glicémica. Cien. Inv. Agr. 38(2): 309-323. La miel de abejas es una substancia natural constituida por una mezcla compleja de carbohidratos, agua y una pequeña proporción de proteínas, vitaminas, minerales y compuestos fenólicos, entre otros constituyentes minoritarios. Utilizada por milenios como alimento y medicina, se le atribuye un sinnúmero de efectos beneficiosos, a saber: aumento de la capacidad antioxidante, modulación del sistema inmune, actividad antimicrobiana, influencia sobre los niveles lipídicos mediante efectos antihipercolesterolémicos y regulación de las respuestas glicémicas, entre otros. Considerando lo anterior, nuestro objetivo es mostrar los efectos de la ingesta de miel sobre la salud, con especial atención en su influencia sobre la regulación glicémica. Diversos estudios han investigado si la miel puede constituir un suplemento nutricional, tanto para individuos saludables como para aquéllos con tolerancia reducida a la glucosa, diabetes y comorbilidades asociadas. Estas investigaciones han 
encontrado que el consumo de miel, en comparación a glucosa y sacarosa, disminuye los niveles glicémicos y los lípidos sanguíneos en sujetos saludables, diabéticos e hiperlipidémicos. Más aún, su ingesta durante períodos prolongados puede reducir, según algunos estudios, los niveles glicémicos en ayunas. Esta evidencia sugiere que el consumo de miel influencia los mecanismos de regulación de los niveles de glucosa plasmática, principalmente mediante un efecto normo- o hipoglicemiante. Según lo anterior, la miel podría constituir un suplemento nutricional en la dieta de individuos saludables y en aquéllos con alteraciones en la regulación glicémica.

Palabras clave: Compuesto nutracéutico, diabetes, flavonoides, miel, nutrición, regulación glicémica, resistencia insulínica.

\section{References}

Abuharfeil, N., R. Al-Oran, and M. Abo-Shehada. 1999. The effect of bee honey on the proliferative activity of human B-and T-lymphocytes and the activity of phagocytes. Food and Agricultural Immunology 11: 169-177.

Agrawal, O.P., A. Pachauri, H. Yadav, J. Urmila, H.M. Goswamy, A. Chaperwal, P.S. Bisen, and G.B.K.S. Prasad. 2007. Subjects with impaired glucose tolerance exhibit a high degree of tolerance to honey. Journal of Medicinal Food 10: 473-478.

Ahmad, A., M.K. Azim, M.A. Mesaik, and R.A. Khan. 2008. Natural honey modulates physiological glycemic response compared to simulated honey and D-glucose. Journal of Food Science 73: H165-H167.

Al-Mamary, M., A. Al-Meeri, and M. Al-Habori. 2002. Antioxidant activities and total phenolics of different types of honey. Nutrition Research 22: 1041-1047.

Álvarez-Suárez, J.M., S. Tulipani, S. Romandini, E. Bertoli, and M. Battino. 2010. Contribution of honey in nutrition and human health: a review. Mediterranean Journal of Nutrition and Metabolism 3: 15-23.

Al-Waili, N.S. 2004. Natural honey lowers plasma glucose, C-reactive protein, homocysteine, and blood lipids in healthy, diabetic, and hyperlipidemic subjects: comparison with dextrose and sucrose. Journal of Medicinal Food 7: 100-107.

Al-Waili, N.S, and A. Haq. 2004. Effect of honey on antibody production against thymus-dependent and thymus-independent antigens in primary and secondary immune responses. Journal of Medicinal Food 7: 491-494.
Aparna, A.R., and D. Rajalakshmj. 1999. Honey Its characteristics, sensory aspects, and applications. Food Reviews International 15: 455-471.

Avicenna. 1999. Canon of Medicine. Kazi Publications. Chicago, USA. 650 pp.

Beretta, G., M. Orioli, and R.M. Facino. 2007. Antioxidant and radical scavenging activity of honey in endothelial cell cultures (EA.hy926). Planta Medica 73: 1182-1189.

Bogdanov, S., P. Martin, and C. Lullmann. 1997. Harmonised methods of the European Honey Commission. Apidologie 28: s1-s59.

Bornet, F., M.J. Haardt, D. Costagliola, A. Blayo, and G. Slama. 1985. Sucrose or honey at breakfast have no additional acute hyperglicaemic effect over an isoglucidic amount of bread in Type 2 diabetic patients. Diabetologia 28: 213-217.

Braguinsky, J. 2002. Prevalencia de la obesidad en América Latina. Anales del Sistema Sanitario de Navarra 25: 109-115.

Cabrera, L., E. Céspedes, R. Nava, and G. Ojeda de Rodríguez. 2006. Actividad antibacteriana noperóxido de mieles zulianas. Revista Científica - Facultad de Ciencias Veterinarias 16: 5565563.

Cheng, H., S.G. Straub, and G.W. Sharp. 2003. Protein acylation in the inhibition of insulin secretion by norepinephrine, somatostatin, galanin, and PGE2. American Journal of Physiology: Endocrinology and Metabolism 285: E287-E294.

Chepulis, L.M. 2007. The effect of honey compared to sucrose, mixed sugars, and a sugar-free diet on weight gain in young rats. Journal of Food Science 72: S224-S229.

Chepulis, L., and N. Starkey. 2008. The long-term effects of feeding honey compared with sucrose and a sugar-free diet on weight gain, lipid pro- 
files, and DEXA measurements in rats. Journal of Food Science 73: H1-H7.

Choi, S.W., I.F. Benzie, S.W. Ma, J.J. Strain, and B.M. Hannigan. 2008. Acute hyperglycemia and oxidative stress: direct cause and effect? Free Radical Biology and Medicine 44: 1217-1231.

Chow, J. 2002. Probiotics and prebiotics: A brief overview. Journal of Renal Nutrition 12: 76-86.

Contreras, P., P. Vigil, A.M. Salgado, and M. Buttinghausen. 2006. Sensibilidad insulínica y niveles circulantes de testosterona se correlacionaron directamente en una población masculina sospechosa de ser resistente a la insulina. International Journal of Morphology 24: 118-119.

Cooper, R. 2007. Honey in wound care: antibacterial properties. GMS Krankenhaushygiene Interdisziplinär 2: 1-3.

Cordain, L., M.R. Eades, and M.D. Eades. 2003. Hyperinsulinemic diseases of civilization: more than just Syndrome X. Comparative Biochemistry and Physiology Part A 136: 95-112.

de Jesús María, D. 1653. Tratado breve de la cultivación de las colmenas y lo que con ellas se ha de acer para su conservación. Observado por el Hermano Francisco de la Cruz, natural de Alhama, en el discurso de casi quarenta años que perseveró en el yermo de Volarque dándose a la consideración y propiedad de las avexas, asistiendo de día y de noche en el colmenar que tienen allí los Carmelitas Descalços. Madrid, España.

del Río, M.J., J.P. Ramírez, M.E. Cortés, G. Martí, A. Godoy, and P. Vigil. 2006. Análisis de resistencia insulínica, tolerancia a la glucosa y testosterona en mujeres jóvenes con síndrome de ovario poliquístico agrupadas por índice de masa corporal. Revista Chilena de Obstetricia y Ginecología 71: 299-306.

del Río, M., P. Contreras, A. Salgado, M. Buttinghausen, and P. Vigil. 2007. Relación entre la sensibilidad insulínica y niveles plasmáticos de testosterona en una población masculina sospechosa de ser resistente a la insulina. Revista Internacional de Andrología 5: 110.

Eaton, S.B., and S.B. Eaton. 2000. Paleolithic vs. Modern diets - Selected pathophysiological implications. European Journal of Nutrition 39: 67-70.

Eriksson, J.W. 2007. Metabolic stress in insulin's target cells leads to ROS accumulation - A hypothetical common pathway causing insulin resistance. FEBS Letters 581: 3734-3742.
Evans, J.L., B.A. Maddux, and I.D. Goldfine. 2005. The molecular basis for oxidative stress-induced insulin resistance. Antioxidants \& Redox Signaling 7: 1040-1052.

Fang, X.K., J. Gao, and D.N. Zhu. 2008. Kaempferol and quercetin isolated from Euonymus alatus improve glucose uptake of 3T3-L1 cells without adipogenesis activity. Life Sciences 82: 615-622.

Fernandes, A.A.H., E.L.B. Novelli, K. Okoshi, M.P. Okoshi, B.P. Di Muzio, J.F.C. Guimarães, and A.F. Junior. 2009. Influence of rutin treatment on biochemical alterations in experimental diabetes. Biomedicine \& Pharmacotherapy 64: 214-219.

Ferrannini, E., and A. Mari 1998. How to measure insulin sensitivity. Journal of Hypertension 16: 895-906.

Fredes, C.P. 2004. Relaciones entre el origen geográfico y botánico de mieles chilenas y el contenido de metales pesados. Tesis para optar al grado de Magíster en Ciencias Vegetales. Facultad de Agronomía e Ingeniería Forestal, Pontificia Universidad Católica de Chile. Santiago, Chile. 33 pp.

Fredes, C., and G. Montenegro. 2006. Contenido de metales pesados y otros elementos traza en mieles de abeja en Chile. Ciencia e Investigación Agraria 33: 57-66.

García, A., D. Soto, and C. Romo. 1986. La miel de abejas, composición química, propiedades y usos industriales. Revista Chilena de Nutrición 14: 185-191.

Garrett, R.H., and C.M. Grisham. 2001. Principles of Biochemistry -With a Human Focus. Brooks/ Cole, USA. p. 223-225.

Hall, M. 2003. Carbohydrates. In: S.C. Anderson, and S. Cockayne (eds.). Clinical Chemistry. Concepts and Applications. McGraw-Hill Medical, New York, USA. pp. 153-178.

Havsteen, B.H. 2002. The biochemistry and medical significance of the flavonoids. Pharmacology and Therapeutics 96: 67-202.

Hayes, G.R., and D.H. Lockwood. 1987. Role of insulin receptor phosphorylation in the insulinomimetic effects of hydrogen peroxide. Proceedings of the National Academy of Sciences of the USA 84: 8115-8119.

Kahn, B.B., and J.S. Flier. 2000. Obesity and insulin resistance. Journal of Clinical Investigation 106: 473-81.

Khan, F.R., Z.U. Abadin, and N. Rauf. 2007. Honey: nutritional and medicinal value. International Journal of Clinical Practice 61: 1705-1707. 
Katsilambros, N.L., P. Philippides, A. Touliatou, K. Georgakopoulus, L. Kofotzouli, D. Frangaki, P. Siskoudis, M. Marangos, and P. Sfikakis. 1988. Metabolic effects of honey (alone or combined with other foods) in type II diabetics. Acta Diabetologica Latina 25: 197-203.

King, H., R.E. Aubert, and W.H. Herman. 1998. Global burden of diabetes 1995-2025: prevalence, numerical estimates and projections. Diabetes Care 21: 1414-1431.

Kobori, M., S. Masumoto, Y. Akimoto, and Y. Takahashi. 2009. Dietary quercetin alleviates diabetic symptoms and reduces streptozotocin-induced disturbance of hepatic gene expression in mice. Molecular Nutrition \& Food Research 53: 859-868.

Kok, N.N., L.M. Morgan, C.M. Williams, M.B. Roberfroid, J.P. Thissen, and N.M. Delzenne. 1998. Insulin, glucagon-like peptide 1, glucose-dependent insulinotropic polypeptide and insulin-like growth factor I as putative mediators of the hypolipidemic effect of oligofructose in rats. Journal of Nutrition 128: 1099-1103.

Kwon, O., P. Eck, S. Chen, C.P. Corpe, J.H. Lee, M. Kruhlak, and M. Levine. 2007. Inhibition of the intestinal glucose transporter GLUT2 by flavonoids. FASEB Journal 21: 366-377.

Lee, Y.S., S. Lee, H.S. Lee, B.K. Kim, K. Ohuchi, and K.H. Shin. 2005. Inhibitory effects of isorhamnetin-3-O-beta-D-glucoside from Salicornia herbacea on rat lens aldose reductase and sorbitol accumulation in streptozotocin-induced diabetic rat tissues. Biological \& Pharmaceutical Bulletin 28: 916-918.

Marsh, K., and J. Brand-Miller. 2005. The optimal diet for women with polycystic ovary syndrome? British Journal of Nutrition 94: 154-165.

Martínez-Hervas, S., M. Fandos, J.T. Real, O. Espinosa, F.J. Chaves, G.T. Sáez, A. Salvador, C. Cerdá, R. Carmena, and J.F. Ascaso. 2008. Insulin resistance and oxidative stress in familial combined hyperlipidemia. Atherosclerosis 199: 384-389.

Mesaik, M.A., M.K. Azim, and S. Mohiuddin. 2008. Honey modulates oxidative burst of professional phagocytes. Phytotherapy Research 22: 14041408.

Middleton, E., C. Kandaswami, and T.C. Theoharides. 2000. The effects of plants flavonoids on mammalian cells: implications for inflammation, heart disease, and cancer. Pharmacological Reviews 52: 673-751.
Molan, P.C. 1992. The antibacterial activity of honey. Bee World 73: 5-28.

Molan, P.C. 1999a. Why honey is effective as a medicine. 1. Its use in modern medicine. Bee World 80: 80-92.

Molan, P.C. 1999b. Selection of honey for use as a wound dressing. Primary Intention 8: 87-92.

Molan, P.C. 2001. Why honey is effective as a medicine. 2. The scientific explanation of its effects. Bee World 82: 22-40.

Montenegro, G., R. Pizarro, G. Ávila, R. Castro, C. Ríos, O. Muñoz, F. Bas, and M. Gómez. 2003. Origen botánico y propiedades químicas de las mieles de la Región Mediterránea Árida de Chile. Ciencia e Investigación Agraria 30: 161-174.

Montenegro, G., and C. Fredes. 2008. Relación entre el origen floral y el perfil de elementos minerales en mieles chilenas. Gayana Botánica 65: 123126.

Montenegro, G., F. Salas, R.C. Peña, and R. Pizarro. 2009. Actividad antibacteriana y antifúngica de mieles monoflorales de Quillaja saponaria, especie endémica de Chile. Фyton 78: 141-146.

Moreira, R.F.A., and C.A.B. De Maria. 2001. Glicídos no mel. Quimica Nova 24: 516-525.

Münstedt, K., M. Bargello, and A. Hauenschild. 2009a. Royal jelly reduces the serum glucose levels in healthy subjects. Journal of Medicinal Food 12: 1170-1172.

Münstedt, K., S. Hoffmann, A. Hauenschild, M. Bülte, R. von Georgi, and A. Hackethal. 2009b. Effect of honey on serum cholesterol and lipid values. Journal of Medicinal Food 12: 624-628.

Muñoz, O., S. Copaja, H. Speisky, R.C. Peña, and G. Montenegro. 2007. Contenido de flavonoides y compuestos fenólicos de mieles chilenas e índice antioxidante. Quimica Nova 30: 848-851.

Mulvihill, E.E., E.M. Allister, B.G. Sutherland, D.E. Telford, C.G. Sawyez, J.Y. Edwards, J.M. Markle, R.A. Hegele, and M.W. Huff. 2009. Naringenin prevents dyslipidemia, apolipoprotein B overproduction, and hyperinsulinemia in LDL receptor-null mice with diet-induced insulin resistance. Diabetes 58: 2198-2210.

Muoio, D.M., and C.B. Newgard. 2004. Insulin resistance takes a trip through the ER. Science 306: 425-426.

Oizumi, T., M. Daimon, Y. Jimbu, W. Kameda, N. Arawaka, H. Yamaguchi, H. Ohnuma, H. Sasaki, and T. Kato. 2007. A palatinose-based balanced formula improves glucose tolerance, serum free 
fatty acid levels and body fat composition. Tohoku Journal of Experimental Medicine 212: 9199.

Ong, K.C., and H.E. Khoo. 1996. Insulinomimetic effects of myricetin on lipogenesis and glucose transport in rat adipocytes but not glucose transport translocation. Biochemical Pharmacology 51: 423-429.

Ong, K.C., and H.E. Khoo. 2000. Effects of myricetin on glycemia and glycogen metabolism in diabetic rats. Life Sciences 67: 1695-1705.

Panda, S., and A. Kar. 2007. Apigenin (4',5,7-trihydroxyflavone) regulates hyperglycaemia, thyroid dysfunction and lipid peroxidation in alloxaninduced diabetic mice. Journal of Pharmacy and Pharmacology 59: 1543-1548.

Pérez-Trueba, G. 2003. Los flavonoides: antioxidantes o prooxidantes. Revista Cubana de Investigación Biomédica 22: 48-57.

Reaven, G.M. 2006. The metabolic syndrome: is this diagnosis necessary? American Journal of Clinical Nutrition 83: 1237-1247.

Samanta, A., A.C. Burden, and G.R. Jones. 1985. Plasma glucose responses to glucose, sucrose, and honey in patients with diabetes mellitus: an analysis of glycaemic and peak incremental indices. Diabetic Medicine 2: 371-373.

Schramm, D.D., M. Karim, H.R. Schrader, R.R. Holt, M. Cardetti, and C.L. Keen. 2003. Honey with high levels of antioxidants can provide protection to healthy human subjects. Journal of Agricultural and Food Chemistry 51: 1732-1735.

Shamala, T.R., Y. Shri Jyothi, and P. Saibaba. 2000. Stimulatory effect of honey on multiplication of lactic acid bacteria under in vitro and in vivo conditions. Letters in Applied Microbiology 30: 453-455.

Shambaugh, P., V. Worthington, and J.H. Herbert. 1990. Differential effects of honey, sucrose, and fructose on blood sugar levels. Journal of Manipulative and Physiological Therapeutics 13: 322-325.

Shambaugh, P., V. Worthington, and J.H. Herbert. 1991. Differential effects of honey, sucrose, and fructose on blood sugar levels. Journal of Manipulative and Physiological Therapeutics 14: 91-92.

Sharma, B., C. Balomajumder, and P. Roy. 2008. Hypoglycemic and hypolipidemic effects of flavonoid rich extract from Eugenia jambolana seeds on streptozotocin induced diabetic rats. Food and Chemical Toxicology 46: 2376-2383.
Shin, J.S., K.S. Kim, M.B. Kim, J.H. Jeong, and B.K. Kim. 1999. Synthesis and hypoglycemic effect of chrysin derivatives. Bioorganic \& Medicinal Chemistry Letters 9: 869-874.

Smukler, S., L. Tang, M. Wheeler, and A. Salapatek. 2002. Exogenous nitric oxide and endogenous glucose-stimulated $\beta$-cell nitric oxide augment insulin release. Diabetes 51: 3450-3460.

Southgate, D.A. 1995. Digestion and metabolism of sugars. American Journal of Clinical Nutrition 62: 203S-211S.

Tapas, A.R., D.M. Sakarkar, and R.B. Kakde. 2008. Flavonoids as nutraceuticals: a review. Tropical Journal of Pharmaceutical Research 7: 10891099.

Thomas, F., and S.J. Mathews. 1963. Piero di Cosimo's discovery of honey. The Art Bulletin 45: 357-360.

Tonks, A.J., R.A. Cooper, K.P. Jones, S. Blair, J. Parton, and A. Tonks. 2003. Honey stimulates inflammatory cytokine production from monocytes. Cytokine 21: 242-247.

van Acker, S.A., D.J. van den Berg, M.N. Tromp, D.H. Griffioen, W.P. van Bennekom, W.J. van der Vijgh, and A. Bast. 1996. Structural aspects of antioxidant activity of flavonoids. Free Radical Biology and Medicine 20: 331-342.

van den Berg, A.J., E. van den Worm, H.C. van Ufford, S.B. Halkes, M.J. Hoekstra, and C.J. Beukelman. 2008. An in vitro examination of the antioxidant and anti-inflammatory properties of buckwheat honey. Journal of Wound Care 17: 172-174, 176-178.

Vigil, P., P. Contreras, J.L. Alvarado, A. Godoy, A.M. Salgado, and M.E. Cortés. 2007a. Evidence of subpopulations with different levels of insulin resistance in women with polycystic ovary syndrome. Human Reproduction 22: 2974-2980.

Vigil, P., M.J. del Río, and M.E. Cortés. 2007b. Síndrome de ovario poliquístico. In: J. Braguinsky (ed.). Obesidad: Saberes y Conflictos. Un Tratado de Obesidad. Editorial Alliance for World Wide Editing, Buenos Aires, Argentina. p. 557566.

Vincent-Desplanques, D., F. Faivre-Defrance, J.L. Wémeau, and M.C. Vantyghem. 2005. Syndromes d'insulinorésistance extrême génétiquement determines. La Revue de Médecine Interne 104: 367-373.

Viuda-Martos, M., Y. Ruiz-Navajas, J. FernándezLópez, and J.A. Pérez-Alvarez. 2008. Functio- 
nal properties of honey, propolis, and royal jelly. Journal of Food Science 73: R117-R124.

Vosloo, M.C. 2005. Some factors affecting the digestion of glycaemic carbohydrates and the blood glucose response. Journal of Family Ecology and Consumer Sciences 33: 1-9.

Wahdan, H.A.L. 1998. Causes of the antimicrobial activity of honey. Infection 26: 26-31.

Wang, X., and G.R. Gibson. 1993. Effects of the in vitro fermentation of oligofructose and inulin by bacteria growing in the human large intestine. Journal of Applied Bacteriology 75: 373-780.

White, J.W., M.H. Subers, and A.I. Schepartz. 1963. The identification of inhibine, the antibacterial factor in honey, as hydrogen peroxide and its origin in a honey glucose-oxidase system. Biochimica et Biophysica Acta 73: 57-70.

White, J.W. 1978. Honey. Advances in Food Research 24: 287-375.
Yaghoobi, N., N. Al-Waili, M. Ghayour-Mobarhan, S.M.R. Parizadeh, Z. Abasalti, Z. Yaghoobi, F. Yaghoobi, H. Esmaeili, S.M.R. Kazemi-Bajestani, R. Aghasizadeh, K.Y. Saloom, and G.A.A. Ferns. 2008. Natural honey and cardiovascular risk factors; effects on blood glucose, cholesterol, triacylglycerole, CRP, and body weight compared with sucrose. TheScientificWorldJournal 8: 463-469.

Yalow, R.S., and S.A. Berson. 1970. Dynamics of insulin secretion in early diabetes in humans. Advances in Metabolic Disorders 1: 95-100.

Zanatta, L., A. Rosso, P. Folador, M.S. Figueiredo, M.G. Pizzolatti, L.D. Leite, and F.R. Silva. 2008. Insulinomimetic effect of kaempferol 3-neohesperidoside on the rat soleus muscle. Journal of Natural Products 71: 532-535.

Zitzmann, M. 2009. Testosterone deficiency, insulin resistance and the metabolic syndrome. Nature Reviews Endocrinology 5: 673-681. 
